\title{
An Empirical Investigation of Factors Predicting the Adoption and Use of Local E-government Services: A Conceptual Framework
}

\author{
Isaac Kofi Mensah ${ }^{1, *}$, Mi Jianing ${ }^{2}$ \\ ${ }^{1}$ Department of Public Administration, School of Management, Harbin Institute of Technology, Harbin, China \\ ${ }^{2}$ School of Management, Harbin Institute of Technology, Harbin China
}

Email address:

1185842364@qq.com (I. K. Mensah), mijianing@126.com ( M. Jianing)

${ }^{*}$ Corresponding author

\section{To cite this article:}

Isaac Kofi Mensah, Mi Jianing. An Empirical Investigation of Factors Predicting the Adoption and Use of Local E-government Services: A Conceptual Framework. Advances in Networks. Vol. 5, No. 2, 2017, pp. 31-39. doi: 10.11648/j.net.20170502.11

Received: March 12, 2017; Accepted: March 24, 2017; Published: November 1, 2017

\begin{abstract}
Local e-government is the application of appropriate Information and Communication Technologies (ICTs) at the local government level to improve the administration and provision of local government services to local residents. The purpose of this conceptual framework is to explore the determinants influencing the intention to adopt and use local egovernment services. This research will also to seek to differentiate between informational and transactional local egovernment services and to examine factors influencing local residents to desire to use either transactional or informational local e-government or both. Factors such as Perceived Usefulness, Perceived Ease of Use, Computer Self-efficacy, Perceived Service Quality, Demographic Factors, Trust in Local Government, Trust in the Internet and Perceived Risk will be investigated. The Technology Acceptance Model (TAM) will be used as the theoretical framework for this study. A wellstructured research questionnaire instrument would be developed and administered to 1,000 potential respondents at four different local government jurisdictions in Ghana. The data gathered would be captured and analyzed with SPSS while a further detailed analysis would be conducted using the Structural Equation Modeling (SEM) method.
\end{abstract}

Keywords: E-government, Local e-government, Public Service Delivery, Local Government, Technology Acceptance Model (TAM)

\section{Introduction}

The administration of central governments could be decentralized to the local government levels with a purpose to bringing government administration and delivery of public service closer to the ordinary citizenry. E-government has been identified as a vehicle through which the decentralization of central government businesses and provision of public services to local residents can be achieved. E-government is the application and use of appropriate Information and Communication Technologies (ICTs), particularly the internet and the web by a government and its public sector organizations to support and redefine the existing or future relations with stakeholders [1]. The application of appropriate e-government technology is to ensure that there is improvement and efficiency in government business and provision of public services to citizens, businesses, and government agencies. The adoption of e-government by the government to enhance delivery of public service has been occasioned by the compelling demand of the New Public Management (NPM) concept which seeks to change the traditional public administration to a state where it can deliver efficient and effective public service to its stakeholders. Two very important trajectories have been created by the combination of e-government and New Public Management: first, has to do with the external perspective on the relationship between government and citizens while the second is concerned with the internal perspective of government with respect to changes within and between bureaucratic organizations [1] 
Local e-government is the application of appropriate ICTs at the local government level to improve and bring the delivery of public service closer to the doorsteps of local residents. Local e-government could be seen as the improvement, effectiveness and efficiency of local government in leading and delivering services to all communities through the use of ICTs with a purpose of central and local government working in partnership to deliver better outcomes for citizens and places, including real challenges for local government in terms of political and managerial leadership, thus enhancing citizen engagement and participation for better service delivery [2]. Local egovernment further refers to information, services or transactions that local governments provide online to citizens using the Internet and Websites [3].

The Government of Ghana has through policy adopted and implemented a number of e-government projects to bring effectiveness, efficiency, transparency and accountability in government interaction with the citizenry. These e-government projects are purposed to bring public service delivery closer to the doorsteps of citizens. The Adoption of e-government by Government of Ghana is to further ensure the faster decentralization of government business and public service delivery to the local government levels (Districts, Municipals, and Metropolitan). The full purpose of local government decentralization in Ghana could be achieved through the adoption of local e-government by Local government authorities at the Districts, Municipals, and Metropolitan levels with a focus on local e-government service delivery to local residents. Whereas there have been studies which have examined the factors influencing local residents intention to adopt and use local e-government services with respect to other countries, that cannot be said of Ghana. In other words, there is no study which has investigated factors influencing local residents' intention to adopt and use local e-government services in Ghana. Hence, this research would attempt to fill this gap.

The main objective of this research is to explore local egovernment service delivery in Ghana and to specifically examine the factors which would influence local residents to adopt and use local e-government service in Ghana. Other objectives of this study are to:

a) examine the current state of local e-government adoption and its impact on local government service delivery in Ghana

b) explore the challenges facing the adoption and implementation of local e-government by local authorities in Ghana.

c) Present an overview of Ghana's decentralization and local government systems.

d) suggest appropriate policy recommendations for local government policymakers and other key stakeholders in Ghana.

This research would further seek to investigate the following research questions:

i. To what extent does the perceived usefulness of informational and transactional local e-government services have a significant influence on the intention of local residents to use both local informational and transactional local e-government services in Ghana?

ii. Does the perceived ease of use of informational and transactional local e-government services have a significant influence on the intention of local residents to use both local informational and transactional local e-government services in Ghana?

iii. Does the perceived ease of use of informational and transactional local e-government services have a positive impact on the perceived usefulness of both informational and transactional local e-government services in Ghana?

iv. Does computer self-efficacy have a positive significant impact on the perceived ease of use of both informational and transactional local e-government services in Ghana?

v. Does computer self-efficacy have a direct positive influence on the intention of local residents to use both informational and transactional local e-government services in Ghana?

vi. Does perceived service quality of informational and transactional local e-government services have a positive impact on the intention of local residents to use both informational and transactional local egovernment services in Ghana?

vii. Do demographic factors such as age, gender and education have a significant impact on the intention of local residents to adopt and use both informational and transactional local e-government services in Ghana?

viii.Do demographic factors such as age, gender, and education have a positive significant influence on computer self-efficacy of local residents in Ghana?

ix. Does Trust in Local Government Authority have a positive impact on the intention of local residents to adopt and use both informational and transactional local e-government services in Ghana?

x. Does Trust in the Internet have a direct impact on the perceived ease of use of both informational and transactional local e-government service delivery in Ghana?

xi. Does perceived risk of informational and transactional local e-government services have a positive influence on the intention of local residents to adopt and use both informational and transactional local egovernment services in Ghana?

xii. Does perceived risk of informational and transactional local e-government services have a positive impact on local residents trust in the Internet?

xiii.Does the intention of local residents to use informational and transactional local e-government services have a positive significant impact on the local residents' actual use of both informational and transactional e-government services in Ghana?

xiv. Does local residents' actual use of informational local e-government services have a significant impact on the 
actual use of transactional local e-government services in Ghana?

\section{Technology Adoption Theories}

There are several theories of technology acceptance and notable among these technology acceptance theories are the Theory of Reasoned Action (TRA) [4], Theory of Planned Behavior (TPB) [5], Innovation Diffusion Theory (IDT) [6], Unified theory of Acceptance and Use of Technology (UTAUT) [7], Extended Technology Acceptance Model (ETAM) [8] and Technology Acceptance Model (TAM) by Davis, [9]. This study will adapt and modify the Technology Acceptance Model (TAM) by Davis (1989) to undertake this research. TAM is therefore considered as the research theoretical framework for this research

The Technology Acceptance Model by Davis [9] is one of the widely used technology adoption theories that have been applied in the study of e-government services adoption because of its potential to provide a theoretical basis for user acceptance and usage behavior of information technology. TAM has been considered to be a robust model to measure technology acceptance behaviors among users both at the level of expertise and across countries [10, 11].
According to the TAM one's acceptance of one form of technology is influenced by his or her voluntary intention to use such a particular technology. This intention to use is also determined by two core belief of TAM, which is perceived usefulness and perceived ease of use of a particular technology. Perceived usefulness is defined as the degree to which an individual believes that using a particular technology or system would enhance his or her productivity [9] while perceived ease of use is defined as the degree to which an individual believes that using a particular system or technology would be free of efforts or challenges [9]. In the context of e-government service adoption, it could be said that the perceived usefulness and perceived ease of use of e-government services would have a direct and positive impact on one's behavioral intention to adopt and use e-government services. The selection of TAM is based on two very vital reasons. First, it has been widely applied, tested and validated in different fields such as ecommerce and mobile e-commerce [12, 13, 14], e-learning $[15,16,17]$, mobile government [18]-[19] and egovernment [20, 21, 22, 23]. Secondly, TAM is considered a reliable instrument and practically can be modified to suit particular situation [14]. The graphical representation of TAM is shown in Figure 1.

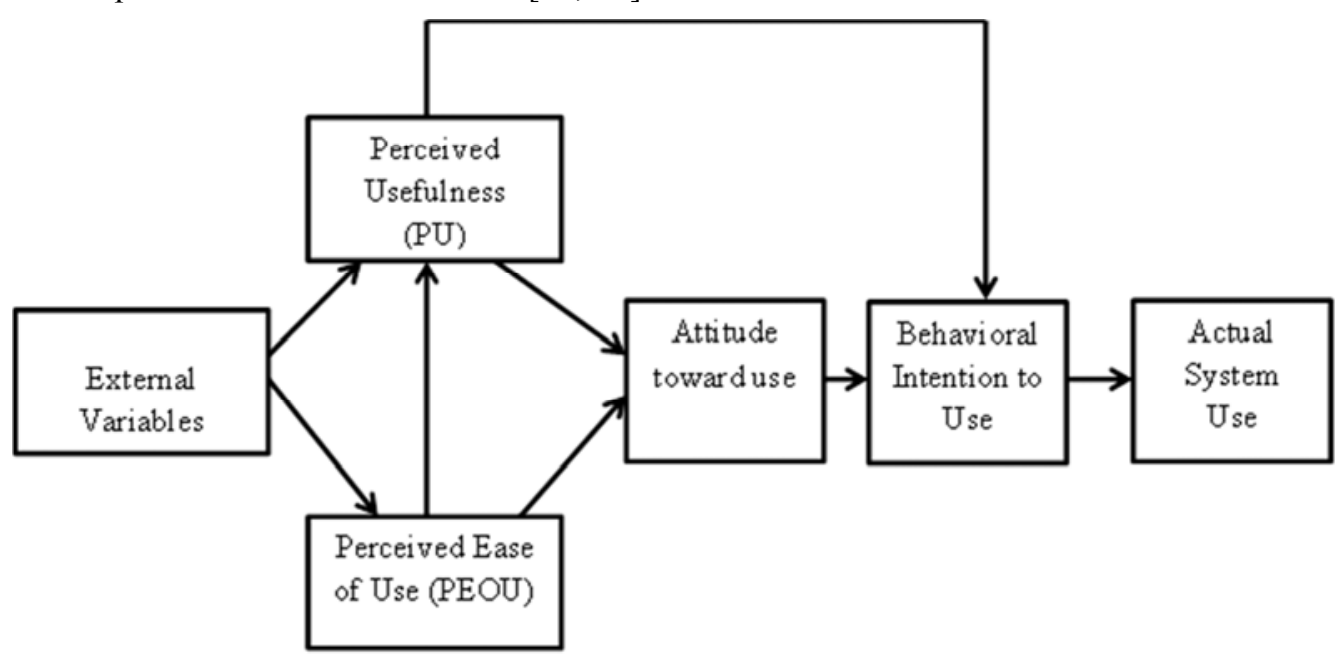

Figure 1. Technology Acceptance Model (TAM) [9].

\section{Research Model}

The research model for this study is depicted in Figure 2. The factor variables under the Informational Local egovernment services such as Trust in Government, Trust in the Internet, Perceived Risk, Perceived Usefulness, Perceived Ease of Use, Computer Self-efficacy, Perceived Service Quality and Demographic Factors are presumed to have a direct significant impact on the intention of local residents to use informational local e-government Services. It also presumed that the intention of local residents to use informational local e-government services would have a direct positive effect on the actual local residents' use of informational e-government services in Ghana.

It is further assumed that the predictors under the transactional local e-government services like Demographic Factors, Perceived Service Quality, Computer Self-efficacy, perceived ease of use, perceived usefulness, perceived risk, Trust in the Internet and Trust in Local Government would have direct and significant impact on the intention of local residents to use transactional local e-government services in Ghana. It is also expected that the intention of local residents to use local e-government services would have a positive direct impact on the actual local residents' use of transactional Local e-government services in Ghana.

Finally, it is projected that the actual local residents' use of informational local e-government services would have a significant positive and direct impact on the actual local residents' use of transactional local e-government services in Ghana. 


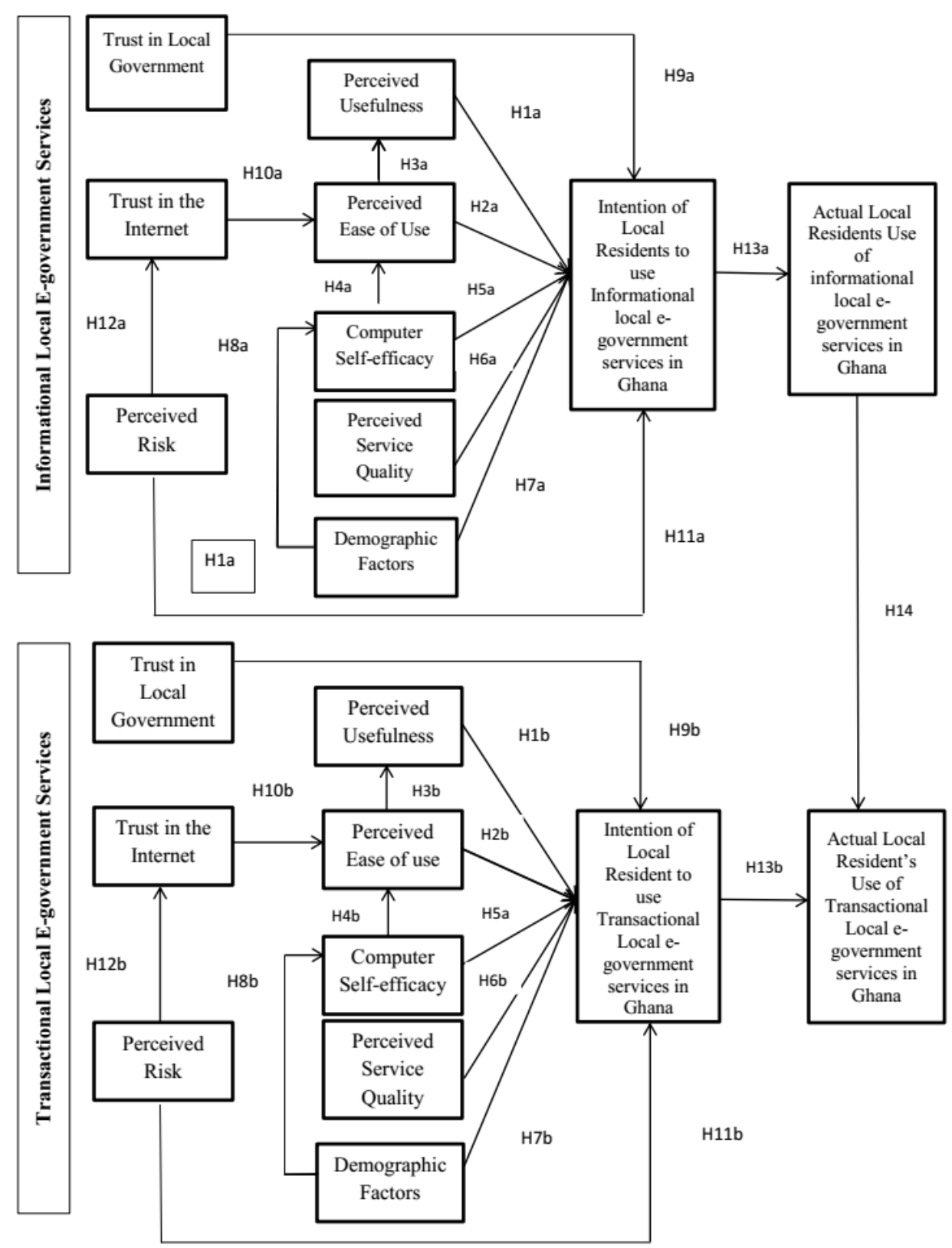

Figure 2. Research Model (Proposed Conceptual Framework).

\section{Research Hypotheses}

This study would investigate the following proposed hypotheses based on the research model illustrated in Figure 2.

\subsection{Hypothesis One (1)}

H1a: Perceived usefulness of informational local egovernment services has a positive influence on the intention of local residents to use informational local e-government services in Ghana.

H1b: Perceived usefulness of transactional local egovernment services has a positive significant impact on the intention of local residents to use transactional local egovernment services

\subsection{Hypothesis One (2)}

H2a: Perceived ease of use of informational local egovernment services has a positive influence on the intention of local residents to use informational local e-government services in Ghana.

$\mathrm{H} 2 \mathrm{~b}$ : Perceived ease of use of transactional local egovernment services has a positive significant impact on the intention of local residents to use transactional local egovernment services.

\subsection{Hypothesis One (3)}

H3a: Perceived ease use of informational local egovernment services has a significant positive influence on 
perceived usefulness of informational local e-government services in Ghana.

H3b: Perceived ease use of transactional local egovernment services has a significant positive influence on perceived usefulness of transactional local e-government services in Ghana.

\subsection{Hypothesis One (4)}

H4a: Computer self-efficacy has a positive influence on the perceived ease of use informational local e-government services in Ghana.

H4b: Computer self-efficacy has a positive influence on the perceived ease of use transactional local e-government services in Ghana.

\subsection{Hypothesis One (5)}

H5a: Computer Self-efficacy has a direct positive influence on the intention of local residents to use informational local e-government services in Ghana.

H5b: Computer Self-efficacy has a direct positive significant impact on the intention of local residents to use transactional local e-government services

\subsection{Hypothesis One (6)}

H6a: Perceived service quality of informational local egovernment services has a positive influence on the intention of local residents to use informational local e-government services in Ghana.

H6b: Perceived service quality of transactional local egovernment services has a positive significant impact on the intention of local residents to use transactional local egovernment services

\subsection{Hypothesis One (7)}

H7a: Demographic factors such as age, gender, and education have a positive influence on the intention of local residents to use informational local e-government services in Ghana.

H7b: Demographic factors such as age, gender, and education have a positive significant impact on the intention of local residents to use transactional local e-government services

\subsection{Hypothesis One (8)}

H8: Demographic factors such as age, gender, and education have a positive significant influence on computer self-efficacy

\subsection{Hypothesis One (9)}

H9a: Trust in Local Government has a direct positive significant influence on the intention of local residents to use informational local e-government services in Ghana.

H9b: Trust in Local Government a direct positive significant impact on the intention of local residents to use transactional local e-government services.

\subsection{Hypothesis One (10)}

H10a: Trust in the Internet has a positive significant impact on the perceived ease of use of informational local egovernment services in Ghana.

H10b: Trust in the Internet has a positive significant impact on the perceived ease of use of transactional local egovernment services in Ghana.

\subsection{Hypothesis One (11)}

H11a: Perceived risk of informational local e-government services have a positive influence on the intention of local residents to use informational local e-government services in Ghana.

H11b: Perceived risk of transactional local e-government services has a positive significant impact on the intention of local residents to use transactional local e-government services

\subsection{Hypothesis One (12)}

H12a: Perceived risk of informational local e-government services has a positive impact on Local residents trust in the Internet.

H12b: Perceived risk of transactional local e-government services has a positive impact on Local residents trust in the Internet.

\subsection{Hypothesis One (13)}

H13a: Intention of local residents to use informational local e-government services has a positive significant influence on the local residents' actual use of informational local e-government services in Ghana.

H13b: Intention of local residents to use transactional local e-government services has a positive significant influence on the local residents' actual use of transactional local egovernment services in Ghana.

\subsection{Hypothesis One (14)}

H14: Local residents' actual use of informational local egovernment services will positively and significantly influence the actual use of transactional local e-government services in Ghana.

\section{Description of the Factors Use in the Study}

The predicting variables used in this study are briefly explained and discussed in the following sections.

\subsection{Perceived Usefulness}

Perceived Usefulness (PU) is the degree to which a person believes that the use of particular computer system applications would improve or hence his or her job performance [9]. Perceived usefulness is considered similar to both the relative advantage in DOI [6] and performance 
expectancy in UTAUT [7]. PU is considered by Davis [9] as one of the most determinants on the behavioral intention to use. It has also been validated that PU has a direct significant impact on the Actual Use of technology related tasks/applications [24, 25, 26]

\subsection{Perceived Ease of Use}

Perceived ease of use (PEOU) is considered as the extent to which a person believes that the use a particular system would be free of challenges or effort [9]. PEOU is also considered similar to the Effort Expectancy in the UTAUT [7]. PEOU has a direct impact on the behavioral intention to us (BI) $[9,27$, 28 ,]. It has also been demonstrated that PEOU has an indirect relationship with BI through PU [29, 26, 30, 31]

\subsection{Computer Self-efficacy}

The self-efficacy theory is a social cognitive theory defined as people's judgment of their ability to organize and perform or execute a particular type of action [32]. It is considered as a particular type of self-assessment that provides an understanding of human behavior and action in relation to a specific task [33, 34, 35,]. Self-efficacy in relation to information technology is considered as the individual perceptions of his or her ability to use computers to accomplish a specific task [36].

Computer self-efficacy is therefore considered as special specific type self-efficacy. This type of self-efficacy can be grouped into two: the first is termed as a general computer self-efficacy which relates to the general use of computers and the second is known as task-specific computer selfefficacy [37]. Previous studies have demonstrated that computer self-efficacy is crucial and has a direct impact on the behavioral intention to adopt and use IT related applications [38, 39, 40, 41,]. It is, however, interesting to note that in the study of Venkatesh et al [7] it was found that self-efficacy does not have a direct effect on the behavioral intention to use $(\mathrm{BI})$.

\subsection{Perceived Service Quality}

Perceived service quality of e-government services is considered as the extent to which e-government services provided by the government and its public sector agencies to facilitate the efficient delivery of effective public services that meets the expected service quality standards citizens require from the government. Service quality is a vital instrument in efforts to building and providing citizen-centric e-government services [42, 43, 44]

\subsection{Demographic Factors}

Demographic factors such as age, gender and education have been found to be vital in the adoption and use of information and communication technology related applications. In relation to Gender, for instance, studies have demonstrated that gender plays a critical role in the adoption and use of new technology related applications [45, 46, 47, $48,49]$. Men are considered to be more likely to use ICT applications than women would do $[45,50,7$,$] . Again it has$ been demonstrated that the way men perceive new technologies and learn faster at using them differ from the perceptions of women towards technology [50, 7].

Age has also been demonstrated through several studies that, Age has an impact on the behavioral intention to use and adopt technology [51, 52]. Older people are considered to have limited skills in using the computer coupled with physical weakness as they age and hence may not be motivated towards using IT related applications [52, 53, 51]. It has also been demonstrated that younger citizens were more likely to visit government websites and adopt egovernment services [54, 55].

Educational levels of citizens have also been found to be crucial in determining the extent to which new technology applications are adopted and used. For instance, in the egovernment literature, it has been found that persons with higher levels of education are more prone to often use informational e-government services [56, 54, 55]. Educational levels have also been found to have a direct impact on the perceived usefulness, perceived ease of use and the behavioral intention to use technology related applications such as e-government [49, 57].

\subsection{Perceived Risk}

Perceived risk is the citizen's subjective expectation of suffering a loss in pursuit of a certain desired outcomes [58]. Perceived risk impacts the decision to use information systems particularly when the decision creates in the consumer feelings of uncertainty, discomfort, anxiety, pain and psychological discomfort [59]. It has been proposed that perceived risk would have an effect on e-government services adoption [58].

\subsection{The Concept of Trust}

The concept of trust has been considered as an important motivating predictor for the adoption and use of egovernment services $[60,61,62,58]$. Trust is defined as the firm belief in the competence of an entity to act dependably, securely and reliably within a specific context [63]. In terms of e-government service adoption, the element of trust can be related to two very important factors which are Trust in the Internet and Government.

Trust in Local government has to do with the perceived citizens' capacity of local government authorities to provide efficient local government services through the adoption and implementation of local e-government. It is also considered as citizens believe that government possesses the political, managerial and technical resources necessary to implement an e-government system [64]. According Sofia [64] citizen confidence in the ability of government agency to provide online services is imperative for the adoption and use of egovernment services.

Trust in the Internet is the citizen believe that the provision of public services through e-government would be secured and protect the privacy of citizens' with regard to the 
information provided particularly when engaging in transactional e-government.

\section{Research Methodology}

The data for this study would be acquired through a research questionnaire instrument to be administered in Ghana. A total of 1000 structured research questionnaire instrument will be designed and administered to potential respondents in four (4) Local Government jurisdictions in Ghana. These Local Government jurisdictions would be selected from four regions in Ghana. The Adenta District Assembly in the Greater Accra Region, Koforidua Municipal Assembly in the Eastern Region, Ketu Municipal Assembly in the Volta Region and the Cape Coast Metropolitan Assembly in the Central Region of Ghana would be the targeted Local Government Jurisdictions for this study. The research instrument would employ five Likert scales of measurement from 1= Strongly Disagree (SD), 2= Disagree (D), $3=\operatorname{Neutral}(\mathrm{N}), 4=$ Agree (A) and 5= Strongly Agree (SA). The data gathered would be captured and analyzed using SPSS version 20. The Structural Equation Modeling will further be applied to analyze the relationship among the variables using Amos Graphic. The questionnaire instrument would be pretested and piloted to ensure that the items in the questionnaire instrument are clear and any ambiguity is removed.

\section{Future Work}

This is a research in progress and hence the future work for this study would include the design and development of the research questionnaire instrument to test and validate the proposed conceptual framework for this study. The instrument would be pretested and piloted with potential respondents in Ghana. The instrument would then be administered to the targeted sample of 1,000 potential respondents. Conduct of detailed literature review. Capture and analyze the data with SPSS. Based on the results from the analysis, appropriate recommendations would be offered for the successful implementation of local e-government in Ghana.

\section{Conclusion}

The conduct of this research would contribute greatly to providing a contextual understanding of local e-government adoption and implementation in Ghana and how this is impacting significantly on improving the delivery of public services at the local government level to local residents. This study would further seek to examine the peculiar factors influencing local residents' intention to adopt and use local e-government services in Ghana. Again, this study would significantly contribute to enriching the academic literature with respect to local e-government service delivery in Ghana.

\section{References}

[1] Homburg VM. F (2004). New Public Management and EGovernment: Trajectories of a Marriage between Managerial and Technological Reform in Government. Innovations through Information Technology, pp. 664-667.

[2] Rahman, Hakikur. "Local E-Government Management: A Wider Window Of E- Governance". Igi-global.com. N.p., 2016. Web. 5 Nov. 2016.

[3] Tan and Koray Velibeyoglu. "Strengthening The KnowledgeBase Of Cities Through ICT Strategies". Igi-global.com. N.p., 2016. Web. 5 Nov. 2016.

[4] Fishbein, M., \& Ajzen, I. (1975). Belief, attitude, intentions, and behavior: An introduction to theory and research. Boston: Addison-Wesley.

[5] Ajzen, I. (1985). From intentions to actions: A theory of planned behavior. In J. Kuhl \& J. Beckman (Eds.), Actioncontrol: From cognition to behavior (pp. 11-39). Heidelberg, Germany: Springer.

[6] Rogers, E. M. (1995). Diffusion of innovations (4th ed.). New York: Free Press.

[7] Venkatesh, V., Morris, M., Davis, G., \& Davis, F. (2003). User acceptance of information technology: Toward a unified view. MIS Quarterly, 27(3),425-478.

[8] Venkatesh, V., \& Davis, F. (2000). A theoretical extension of the technology adoption model: Four longitudinal field studies. Management Science, 46, 186-204.

[9] Davis, F. (1989). Perceived usefulness, perceived ease of use, and user acceptance of information technology. MIS Quarterly, 13(3), 319-340.

[10] Gefen, D. (2002). Customer Loyalty in e-Commerce. Jr. of the Association for Information Systems. 3: 27-51.

[11] Taylor, S., \& Todd, P. (1995). Understanding Information Technology usage: A test of competing models. Information Systems Research. 6: 144-176.

[12] Gefen, D., Elena, K., \& Straub, D. (2003). Trust and TAM in online shopping: An integrated model. MIS Quarterly, 27(1), 51-90.

[13] Pavlou, P., \& Fygenson, M. (2006). Understanding and predicting electronic commerce adoption: An extension of the theory of planned behavior. MIS Quarterly, 30(1), 115-143.

[14] Fu, J. R., Farn, C. K., \& Chao, W. P. (2006). Acceptance of electronic tax filing: A study of taxpayer intentions. Information \& Management, 43(1), 109-126.

[15] Cheung, R., \& Vogel, D. (2013). Predicting user acceptance of collaborative technologies: An extension of the technology acceptance model for elearning. Computers \& Education, 63, $160-175$.

[16] Mohammadi, H. (2015). Investigating users' perspectives on e-learning: An integration of TAM and IS success model. Computers in Human Behavior, 45, 359-374.

[17] Al-Gahtani, S. S. (2014). Empirical investigation of e-learning acceptance and assimilation: a structural equation model. Applied Computing and Informatics. http://dx.doi.org/10.1016/j.aci.2014.09.001. 
[18] Liu, Y., Li, H., Kostakos, V., Goncalves, J., Hosio, S., \& Hu, F. (2014). An empirical investigation of mobile government adoption in rural China: A case study in Zhejiang province. Government Information Quarterly, 31(3), 432-442.

[19] Wang, C. (2014). Antecedents and consequences of perceived value in Mobile Government continuance use: An empirical research in China. Computers in Human Behavior, 34, 140 147.

[20] Al-Hujran, O., Aloudat, A., \& Altarawneh, I. (2013). Factors influencing citizen adoption of e-government in developing countries: The case of Jordan. International Journal of Technology and Human Interaction (IJTHI), 9(2), 1-19.

[21] Alomari, M., Woods, P., \& Sandhu, K. (2012). Predictors for e-government adoption in Jordan: Deployment of an empirical evaluation based on a citizen-centric approach. Information Technology \& People, 25(2), 207-234.

[22] Lin, F., Fofanah, S., \& Liang, D. (2011). Assessing citizen adoption of e-government initiatives in Gambia: A validation of the technology acceptance model in information systems success. Government Information Quarterly, 28(2), 271-279.

[23] Isaac Kofi Mensah (2017): Citizens' Readiness to Adopt and Use E-government Services in the City of Harbin, China, International Journal of Public Administration, DOI: $10.1080 / 01900692.2016 .1263658$ http://dx.doi.org/10.1080/01900692.2016.1263658

[24] Masa'deh, R., Tarhini, A., Mohammed, A. B., \& Maqableh, M. (2016). Modeling Factors Affecting Student's Usage Behaviour of E-Learning Systems in Lebanon. International Journal of Business and Management, 11(2), 299-312. http://dx.doi.org/10.5539/ijbm.v11n2p299

[25] Obeidat, B. Y., Al-Suradi, M., Masa'deh, R., \& Tarhini, A. (2016). The Impact of Knowledge Management on Innovation: An Empirical Study on Jordanian Consultancy Firms. Management Research Review, 39(12), 33-52.

[26] Alalwan, A. A., Dwivedi, Y., Rana, N. P., \& Williams, M. D. (2016). Consumer adoption of mobile banking in Jordan: Examining the role of usefulness, ease of use, perceived risk and self-efficacy. Journal of Enterprise Information Management, 29(1), 118-139. http://dx.doi.org/10.1108/JEIM04-2015-0035

[27] Masa'deh, R., Tarhini, A., Al-Dmour, R. H., \& Obeidat, B. Y. (2015). Strategic IT-Business Alignment as Managers' Explorative and Exploitative Strategies. European Scientific Journal, 11(7), 437-457.

[28] Esterhuyse, M., \& Scholtz, B. (2016). The Intention to Use ELearning in Corporations. In Proceedings of the 2nd International Conference on Information Resources Management (pp. 3-18). Cape Town, South Africa.

[29] Ramirez-Anormaliza, R., Sabate, F., \& Llinàs-Audet, X. (2016). The acceptance and use of the e-learning systems among the university teachers in Ecuador, In Proceedings of EDULEARN16 Conference (pp. 3666-3674). Barcelona, Spain.

[30] Altamony, H., Tarhini, A., Al-Salti, Z., Gharaibeh, A., \& Elyas, T. (2016). The relationship between Change Management Strategy and Successful Enterprise Resource Planning (ERP) Implementations: A Theoretical Perspective. International Journal of Business Management and Economic Research, 7(4), 690-703.
[31] Almajali, D., Masa'deh, R., \& Al-Lozi, M. (2016). Determinants of the Actual Use of E-Learning Systems: An Empirical Study on Zarqa University in Jordan. Journal of Social Sciences, 5(2), 172-200.

[32] Bandura, A. (1986). Social foundations of thought and action: A social cognitive theory. Englewood Cliffs, NJ: Prentice Hall.

[33] Bandura, A. (1997). Self-Efficacy: The Exercise of Control (p. 604). New York, W.H. Freeman.

[34] Alenezi, H., Tarhini, A., \& Sharma, S. K. (2015). Development of a Quantitative Model to Investigate the Strategic Relationship between Information Quality and EGovernment Benefits. Transforming Government: People, Process and Policy, 9(3), 324-351. http://dx.doi.org/10.1108/TG-01-2015-0004

[35] Alalwan, A. A., Dwivedi, Y. K., Rana, N. P., Lal, B., \& Williams, M. D. (2015). Consumer adoption of Internet banking in Jordan: Examining the role of hedonic motivation, habit, self-efficacy and trust. Journal of Financial Services Marketing, 20(2), 145-157. http://dx.doi.org/10.1057/fsm.2015.5.

[36] Compeau, D. R., \& Higgins, C. A. (1995). Computer selfefficacy: Development of a measure and initial test. MIS quarterly, 19(2), 189-211. http://dx.doi.org/10.2307/249688

[37] Marakas, G. M., Mun, Y. Y., \& Johnson, R. D. (1998). The multilevel and multifaceted character of computer selfefficacy: Toward clarification of the construct and an integrative framework for research. Information systems research, 9(2), 126-163. http://dx.doi.org/10.1287/isre.9.2.126

[38] Guo, Y., \& Barnes, S. (2007). Why people buy virtual items in virtual worlds with real money. ACM SIGMIS Database, 38(4), 69-76. http://dx.doi.org/10.1145/1314234.1314247

[39] Yi, M. Y., \& Hwang, Y. (2003). Predicting the use of webbased information systems: Self-efficacy, enjoyment, learning goal orientation, and the technology acceptance model. International Journal of Human-Computer Studies, 59(2), 431449. http://dx.doi.org/10.1016/S1071-5819(03)00114-9

[40] Chang, S. C., \& Tung, F. C. (2008). An empirical investigation of students' behavioural intentions to use the online learning course websites. British Journal of Educational Technology, 39(1), 71-83.

[41] Darawsheh, S., ALshaar, A., Masa'deh, R., \& AL-Lozi, M. (2016). The degree of heads of departments at the University of Dammam to practice transformational leadership style from the point of view of the faculty members. Journal of Social Sciences, 5(1), 56-79.

[42] A. Ancarani, "Towards Quality e-Service in the Public Sector: The Evolution of Web Sites in the Local Public Service Sector", Managing Service Quality, (15:1), 2005, pp. 6-23.

[43] J. Buckley, "E-Service Quality and the Public Sector", Managing Service Quality, (13:6), 2003, pp. 453-462.

[44] G. Teicher, O. Hughes, and N. Dow, "E-Government: A New Route to Public Sector Quality", Managing Service Quality, (12:6), 2002, pp. 384-393.

[45] Venkatesh, V. \& Morris, M. G. (2000) Why don't men ever stop to ask for directions? Gender, social influence, and their role in technology acceptance and usage behavior. MIS Quarterly, 24, 115-139. 
[46] Chung, J. E., Park, N., Wang, H., Fulk, J., \& McLaughlin, M. (2010). Age differences in perceptions of online community participation among non-users: An extension of the Technology Acceptance Model. Computers in Human Behavior, 26(6), 1674-1684. http://dx.doi.org/10.1016/j.chb.2010.06.016

[47] King, W. R., \& He, J. (2006). A meta-analysis of the technology acceptance model. Information \& Management, 43(6), 740-755. http://dx.doi.org/10.1016/j.im.2006.05.003

[48] Wang, Y. S., Wu, M. C., \& Wang, H. Y. (2009). Investigating the determinants and age and gender differences in the acceptance of mobile learning. British Journal of Educational Technology, 40(2), 92-118. http://dx.doi.org/10.1111/j.14678535.2007.00809.x

[49] Sun, H., \& Zhang, P. (2006). The role of moderating factors in user technology acceptance. International Journal of Human$\begin{array}{llll}\text { Computer } & \text { Studies, } & \text { 64(3), }\end{array}$ http://dx.doi.org/10.1016/j.ijhcs.2005.04.013

[50] Gefen, D. \& Straub, D. W. (1997) Gender differences in perception and adoption of e-mail: an extension to the technology acceptance model. MIS Quarterly, 21, 389-400.

[51] Morris, M. G. \& Venkatesh, V. (2000) Age differences in technology adoption decisions: implications for a changing workforce. Personnel Psychology, 53, 375-403.

[52] Igbaria, M. \& Parasuraman, S. (1989) Path analytic study of individual characteristics, computer anxiety and attitudes toward microcomputers. Journal of Management, 15, 373-388

[53] Birren, F., Woods, A. \& Williams, M. (1980) Behavioral slowing with age: causes, organization, and consequences. In: Aging in the 1980s, Poon, L. W. (ed.), pp.293-308. American Psychological Association, Washington DC, USA.

[54] Thomas, J. C., \& Streib, G. (2003). The new face of government: Citizen-initiated contacts in the era of egovernment. Journal of Public Administration Research and Theory, 13(1), 83-102.

[55] Hart-Teeter. (2003). The new e-government equation: Ease, engagement, privacy and protection. Retrieved March 21, 2017, from http://www.cio.gov/documents/egovpoll2003.pdf
[56] Shelley, M., Thrane, L., Shulman, S., Lang, E., Beiser, S., Larson, T., et al. (2004). Digital citizenship. Social Science Computer Review, 22, 256-269.

[57] Mahmood, M. A., Hall, L., \& Swanberg, D. L. (2001). Factors affecting information technology usage: A meta-analysis of the empirical literature. Journal of Organizational Computing and Electronic Commerce, 11(2), 107-130. http://dx.doi.org/10.1207/S15327744JOCE1102_02

[58] M. Warkentin, D. Gefen, P.A. Pavlou, and M. Rose, "Encouraging Citizen Adoption of e-Government by Building Trust", Electronic Markets, (12:3), 2002, pp. 157-162.

[59] Featherman, M.S. and Pavlou, P.A. (2003) Predicting eServices Adoption: A Perceived Risk Facets Perspective. International Journal of Human-Computer Studies, 59, 451474. http://dx.doi.org/10.1016/S1071-5819(03)00111-3

[60] D. Gefen, M. Warkentin, P. A. Pavlou, and G. M. Rose, "EGovernment Adoption", Proceedings of the 8th Americas Conference on Information Systems, 569-76. Dallas, Texas, U.S.A., August 9-11, 2002.

[61] J. K. Lee, S. Braynov, H. R. Rao, "Effects of a Public Emergency on Citizens Usage Intention Toward EGovernment: A Study in the Context of War in Iraq", Proceedings of the 24th International Conference on Information Systems, Seattle, Washington, 2003, pp. 896-902.

[62] C. W. Tan, S. L. Pan, and E. T. K. Lim, "Towards the Restoration of Public Trust in Electronic Governments: A Case Study of the E-Filing System in Singapore", Proceedings of the 38th Annual Hawaii International Conference on System Sciences, Computer Society Press, 2005, pp. 1-10.

[63] Grandison, T. \& Sloman, M. (2000). A Survey of Trust in Internet Applications. IEEE Communications Survey and Tutorials, 3 .

[64] Sofia Elena Colesca (2009). Understanding Trust in eGovernment. Inzinerine Ekonomika-Engineering Economics(3). 2009 ECONOMICS OF ENGINEERING DECISIONS. 